\title{
Sea level - geomagnetic polarity correlation as consequence of rotation geodynamics
}

\author{
Valentin Krassilov", Sophia Barinova \\ Inst. of Evolution, University of Haifa, Haifa, Israel \\ Email address: \\ vakrassilov@gmail.com (V. Krassilov),barinova@research.haifa.ac.il (S. Barinova)
}

\section{To cite this article:}

Valentin Krassilov, Sophia Barinova. Sea Level - Geomagnetic Polarity Correlation as Consequence of Rotation Geodynamics. Earth Science, Vol. 2, No. 1, 2013, pp. 1-8. doi: 10.11648/j.earth.20130201.11

\begin{abstract}
The general tendencies of sea level and geomagnetic polarity evolution represented by their respective polynomial trend lines are metrically congruent and roughly coincident at the first order and prevailingly at the second order periodicities. Our analysis reveals chronological correlation of sea level highs and lows with the quiet and agitated states of geomagnetic field, both causally related to the density-dependent rotation forcing of oceanic/continental crust and the inner/outer core masses respectively. Their correlation thus confirms the role of rotation perturbations as a common pacesetter of the Earth's surface and interior processes.
\end{abstract}

Keywords: Sea level; Geomagnetic reversals; Rotation geodynamics; Geochronology

\section{Introduction}

Since the early XIX century to the present day, sea level change was recognized, although on different theoretical premises (diluvialism and fluvialism [1]), as the major factor of paleogeography of a decisive, or at least significant, impact on biological evolution. In stratigraphic sequences, sea level fluctuations are represented by alternations of marine/non-marine facies corresponding to advances/retreats of shore lines (coastal onlaps). Evidence of sea level change comes from the facies records of depth changes and the concomitant erosion fluctuations on land. Chronological correlation of such local records over vast cratonic areas indicates global scale events.

Quantitative estimates of sea level changes depend on what is accepted as null level, e.g. the present day sea level, mean sea level or statistical norm for a time interval, the apparently conventional evaluations. However, on the global scale, the present day shore lines approach the geological boundaries of continental and oceanic crust density domains, the thinner and denser oceanic crust being covered by sea, the thicker continental crust being largely exposed as land or locally inundated. Through geological history, shore lines had repeatedly advanced over the present day land masses far beyond their present extent, whereas sea retreats below the present level seem exceptional. These and related observations makes sea level change analyzable as a hydrospheric effect of differential density-depended acceleration of oceanic and continental crust domains [2]. In this paper, the rotation sea level model is further elaborated by revealing correlation between sea level change and geomagnetic reversals, an explicably rotation phenomenon.

\section{Material and Methods}

Recent compilation of sea level data [3], based on [4 - 6] are correlated with the geomagnetic polarity chart by Ogg et al. [7] brought to the same time scale. Sea level fluctuations are represented as a generalized sea level curve with highs and lows relative to the present day level. The geomagnetic polarity scale is arbitrary divided into the longer than 5 million years (myr) intervals (magnetochrons) that are designated as 'constant' of either normal $(\mathrm{N})$ or reversed $(\mathrm{R})$ polarity, 'semiconstant' of one or another polarity obviously prevailing $(\mathrm{Nr}, \mathrm{Rn})$, and mixed $(\mathrm{M})$ of both polarities equally represented or nearly so. Correlation of sea level fluctuations and geomagnetic polarity is inferred from the observed chronological correspondence of sea level highs and lows to the constant (semiconstant) vs. mixed polarity magnetochrons (Table 1; Fig. 1).

In order to compare the Phanerozoic trends of sea level and geomagnetic polarity change, the generalized sea level curve is reconstructed by plotting sea level with 1 myr interval against durations of polarity reversion intervals (Fig. 2). Standard deviation line of the graph represents the statistically normal sea level for 542 myr. The sea level highs 
(SLH) and lows (SLL), corresponding to the thalassocratic and geocratic epeirochrons respectively, can now be assessed against this level. Chronological correlation of sea

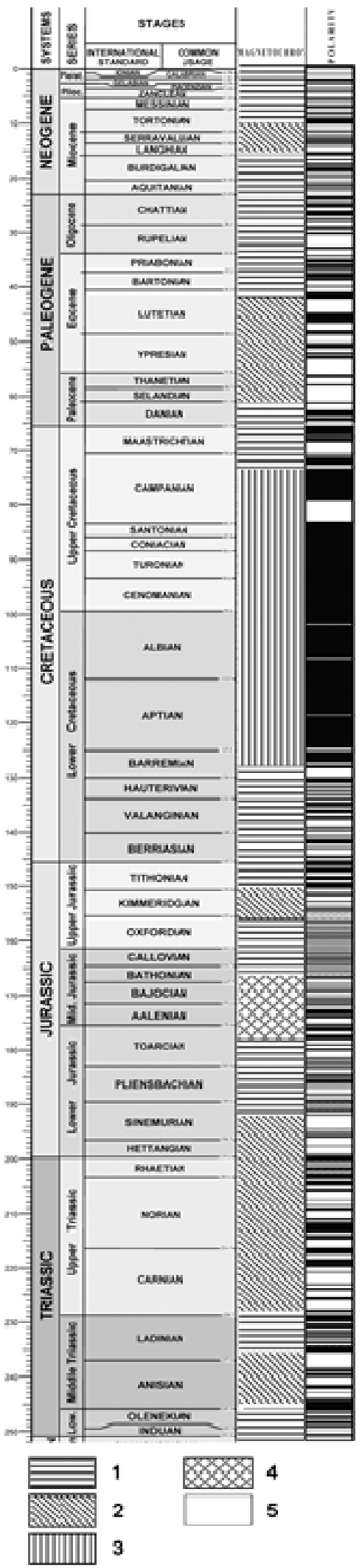

level and geomagnetic reversals is expressed by the coincidence of peaks and troughs of their respective polynomial trend lines (Fig. 2).
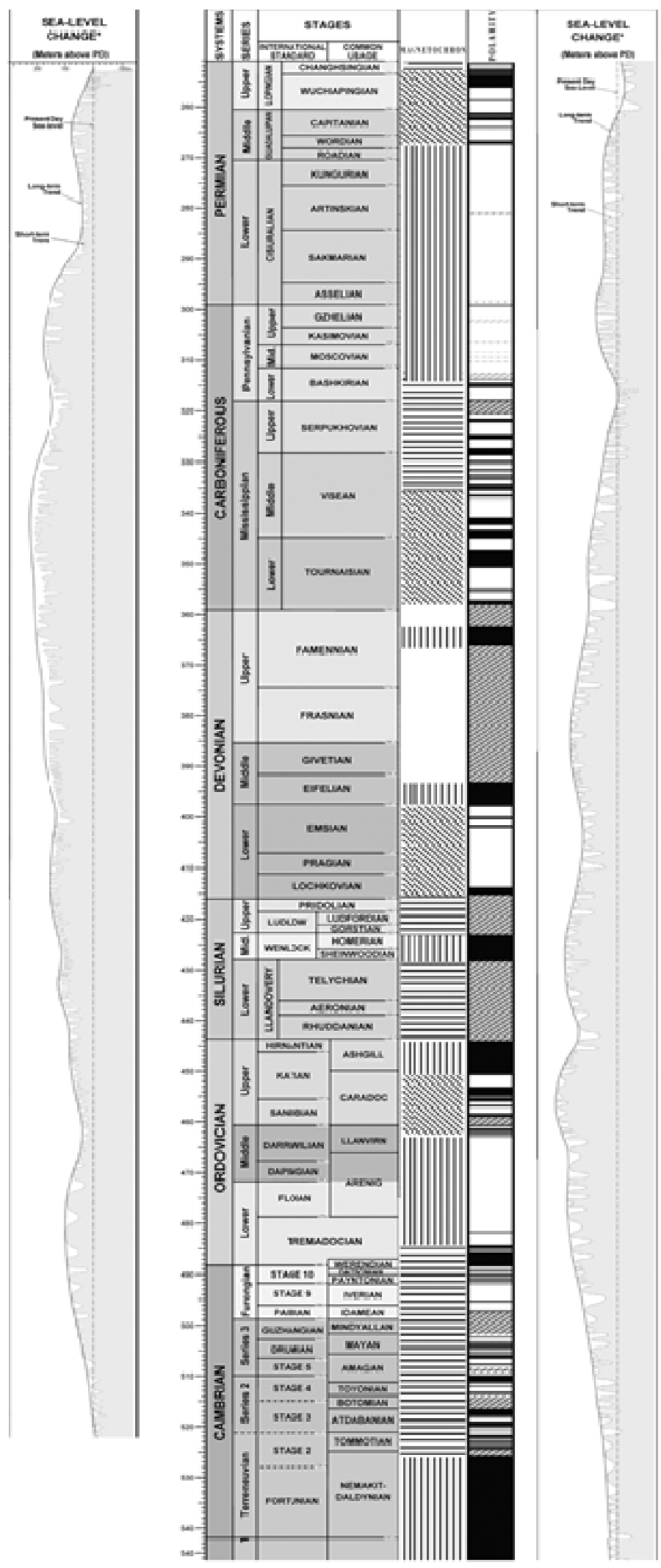

Figure 1. The arbitrary defined magnetochrons of mixed, $M$ (1), semi-constant reversed/normal, Rn (2), constant, N,R (3), semi-constant normal/reversed, $\mathrm{Nr}$ (4), and uncertain polarities (5) inserted against sea level [3] and polarity reversal sequences [7]. 
Table 1. Chronology of sea level cycles and their correlation with geomagnetic polarity scale.

\begin{tabular}{|c|c|c|c|c|c|}
\hline I order epeirochrons & Stage & Мa & Magnetochron & Polarity & \\
\hline SLL1 & Cambrian geocratic & Tommotian-Tremadocian & $550-522$ & Cambrian mixed & M \\
\hline SLH1 & Mid-Paleozoic talassocratic & Tremadocian-Emsian & $522-335$ & $\begin{array}{l}\text { Mayero superchron - } \\
\text { Sayan hyperchron }\end{array}$ & $\begin{array}{l}\mathrm{R}-\mathrm{M} \\
\mathrm{Rn}\end{array}$ \\
\hline SLL2 & Paleozoic/Mesozoic geocratic & Visean-Ladinian & $335-230$ & $\begin{array}{l}\text { Carboniferous mixed series - } \\
\text { E series } \\
\text { E series, M series, }\end{array}$ & $\begin{array}{l}\mathrm{M} \\
\mathrm{Rn} \\
\mathrm{Rn}\end{array}$ \\
\hline SLH2 & Meso-Cenozoic talassocratic & Carnian-Rupelian & $230-34$ & $\begin{array}{l}\text { K Normal- } \\
\text { C13 }\end{array}$ & $\begin{array}{l}\mathrm{M} \\
\mathrm{N}\end{array}$ \\
\hline SLL 3 & Oligocene - Present geocratic & Rupelian-Present & $34-0$ & $\mathrm{C} 1-\mathrm{C} 12$ & $\mathrm{M}, \mathrm{Rn}$ \\
\hline \multicolumn{6}{|l|}{ Sea level peaks } \\
\hline & Sea level troughs & $\begin{array}{l}\text { Caradocian } \\
\text { Llandoverian/Wenlockian } \\
\text { Givetian/Frasnian }^{+} \\
\text {Mid-Tournaisian } \\
\text { Gzhelian/Asselian } \\
\text { Norian } \\
\text { Bajocian/Bathonian } \\
\text { Kimmeridgian/Tithonian } \\
\text { Santonian/Campanian } \\
\text { Ypresian } \\
\text { Serravallian/Tortonian } \\
\text { Arenigian/Llanvirnian } \\
\text { Ashgillian/Llandoverian } \\
\text { Pragian/Emsian } \\
\text { Famennian/Tournaisian } \\
\text { Serpuchovian/Bashkirian } \\
\text { Changhsingian/Induan } \\
\text { Hettangian/Sinemurianian } \\
\text { Berriasian/Valanginian- } \\
\text { Danian/Selandian+ } \\
\text { Rupelian/Chattian }\end{array}$ & $\begin{array}{l}458 \\
428 \\
387 \\
351 \\
302 \\
213 \\
168 \\
151 \\
84 \\
53 \\
12 \\
466 \\
443 \\
406 \\
357 \\
318 \\
251 \\
197 \\
138 \\
63 \\
30 \\
\end{array}$ & $\begin{array}{l}\text { "Poorly known" } \\
\text { Carbon mixed } \\
\text { Kiaman } \\
\text { E14/E15 } \\
\text { M22-M24 } \\
\text { Cretaceous N/C } 33 \\
\text { C21/C22 } \\
\text { "Poorly known" } \\
\text { Carbon mixed } \\
\text { Carbon mixed } \\
\text { Illawara } \\
\text { M15/M16 } \\
\text { C26/C/27 } \\
\text { C9/C10 }\end{array}$ & $\begin{array}{l}\mathrm{Rn} \\
\mathrm{M} / \mathrm{N} \\
\mathrm{T} \\
\mathrm{Rn} \\
\mathrm{R} \\
\mathrm{Rn} \\
\mathrm{Rn} \\
\mathrm{Rn} \\
\mathrm{N} / \mathrm{R} \\
\mathrm{Rn} \\
\mathrm{Rn} \\
\mathrm{N} / \mathrm{M} \\
\mathrm{NM} \\
\mathrm{T} \\
\mathrm{M} \\
\mathrm{M} \\
\mathrm{M} \\
\mathrm{Rn} \\
\mathrm{M} \\
\mathrm{Rn} \\
\mathrm{M}\end{array}$ \\
\hline
\end{tabular}

Symbols ${ }^{+}$and $^{-}$signify slightly below or slightly above the conventional stage boundary.

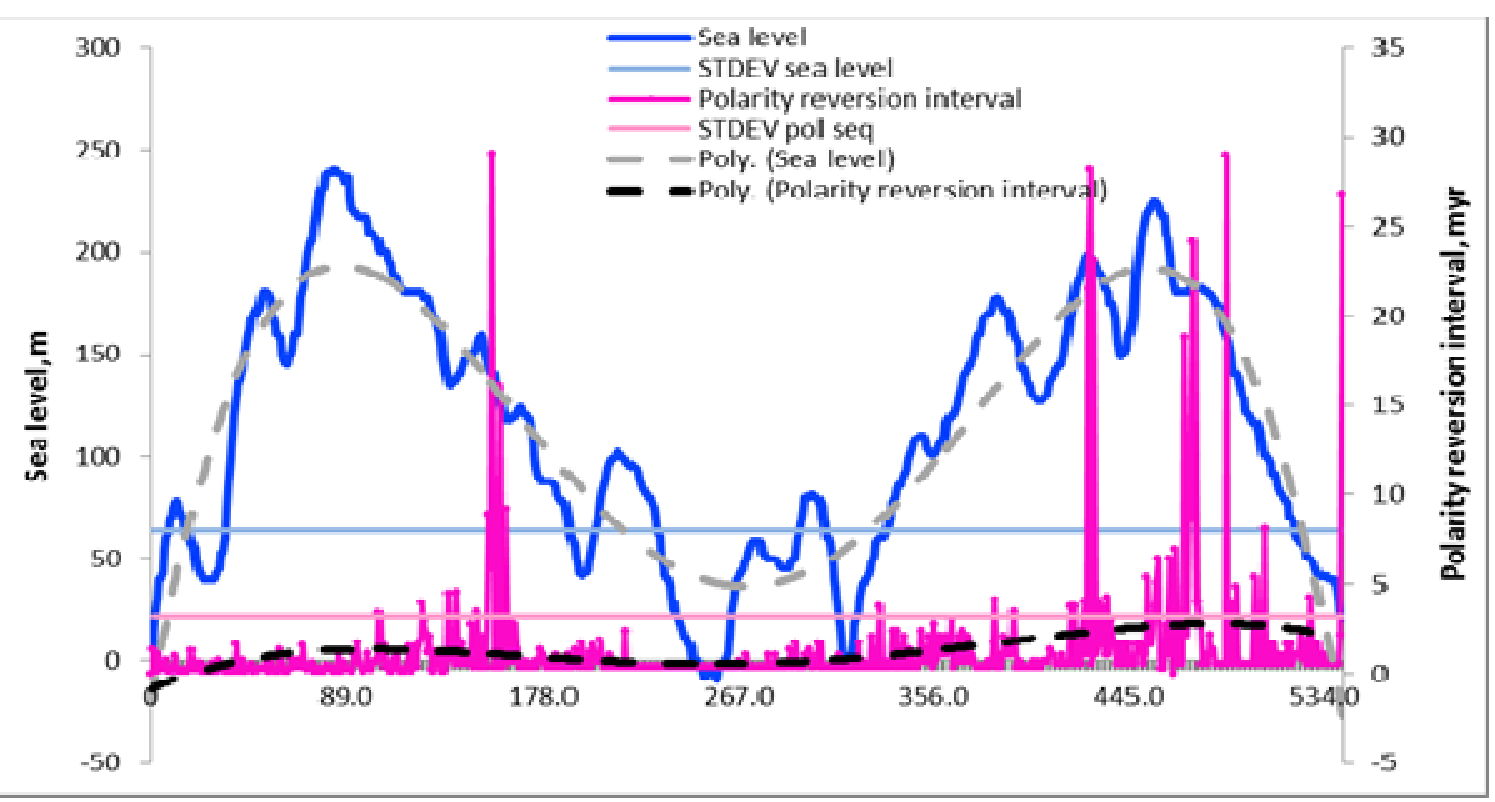

Figure 2. Curves and polynomial trend lines of sea level (data after [3]) and geomagnetic polarity intervals (data after [7]) over 534 myr. Standard deviation lines $(S T D E V)$ represent statistically normal sea level and reversal frequency, respectable.

\section{Results}

\subsection{Sea Level}

The generalized sea level curve (Fig. 1) is divisible into the first order highs and lows, comprising the second order cycles. It is elevated above the present day level except during the end-Permian low that separates the Paleozoic and Meso-Cenozoic megacycles (Table 1). The Paleozoic cycle 
starts with a broad Ediacarian - Cambrian low (SLL1), gradually ascending through the Early - Middle Ordovician to the Late Ordovician (Caradocian) peak (SLH1), and remains high until about the Devonian/Carboniferous boundary, from where a great descend starts and extends over the Mesozoic/Paleozoic transition. The secondary Paleozoic highs have their turning points at about the Early / Middle Ordovician ( mid-Arenigan) , Silurian / Devonian ( mid-Wenlockian ), and the Middle / Late Devonian (Givetian / Frasnian) boundaries. A low flat-topped rise extends between the deep lows at the Mississippian/Pennsylvanian boundary and in the end-Permian (Wuchiapingian/Changhsingian).

The Meso-Cenozoic interval between the end-Permian and Pleistocene lows begins with a very long descend over a series of the sequentially increasing secondary peaks in the Late Triassic (Norian), mid-Jurassic (Bajocian), Late Jurassic (Kimmeridgian-Tithonian) to the Late Cretaceous (Santonian-Campanian) high, from where a descending trend leads through a series of the sequentially decreasing peaks in the Eocene (Ypresian-Lutetian) and Miocene (Serravalian-Tortonian) to the recent low.

Because the present day sea level is the lowest for more than 500 myr of the plotted sea level change, the highs and lows of the generalized sea level curve are arbitrary, with ill-defined turning points. For more objective evaluation of sea-level trends, we re-plotted sea levels with 1 myr interval (Fig. 2). Standard deviation line of the plot approximates the statistical normal sea level for 542 myr. Sea level rises and falls (thalassocratic vs. geocratic epeirochrons) can be objectively assessed against this level. Thus normalized, the sea level curve shows the first order lows (geocratic megachrons) over the Cambrian, Upper Pennsylvanian mid-Triassic, and Oligocene-Pleistocene, divided by the mid-Paleozoic and Meso-Cenozoic sea level highs (thalassocratic megachrons), complicated by the secondary peaks and troughs.

The Cambrian-Mississippian first order cycle is subdivided by the relatively shallow depressions in the mid-Ordovician Arenigian/Llanvirnian, $466 \mathrm{Ma}$ ), over the Ordovician/Silurian transition (Ashgillian/Llandoverian, $443 \mathrm{Ma}$ ), in the Early Devonian (Pragian/Emsian, $406 \mathrm{Ma}$ ), as well as across the Carboniferous/Devonian boundary (Famennian/Tournaisian, $359 \mathrm{Ma}$ ). with a broad flat-topped high in the Tremadocian-Arenigian, 488-477 Ma, the fairly prominent highs in the mid-Caradocian (458 Ma), Llandoverian/Wenlockian, $428 \mathrm{Ma}$, Frasnian/Gvetian, $365 \mathrm{Ma}$, and with a subordinate peak at 351 Ma below the Tournaisian/Visean boundary. The Early-Middle Paleozoic cycles are thus of a geochronological epoch scale.

The Meso-Cenozoic cycle between the Pleistocene and the end-Permian lows comprises a broad, about 50 myr duration, Albian-Campanian rise, the peak of which is skewed to the end of this interval. The second order cycles, roughly corresponding to the geochronological systems and series, are divided by the sea level troughs at about the Oligocene/Miocene boundary (Ruppelian/Chattian, $23 \mathrm{Ma}$ ) as well as slightly above the Cretaceous/Tertiary (Danian/ Selandian, $63 \mathrm{Ma}$ ), Jurassic/Cretaceous (138 Ma), and the Triassic/Jurassic (Hettangian/Sinemurian, $199.5 \mathrm{Ma})$ boundaries. The most prominent second order peaks occur at about the middle of the Triassic (217 Ma), Jurassic (151 Ma), Late Cretaceous (Santonian/Campanian, $84 \mathrm{Ma}$ ), Palaeogene (53 Ma) and Neogene (12 Ma).

\subsection{The Geomagnetic Polarity Scale}

The geomagnetic polarity scale [7] is a sequence of normal $(\mathrm{N})$ and reversed $(\mathrm{R})$ intervals. "Transitional" intervals (T) correspond to relatively weak dipole field dominated by multiple components, probably represented by "uncertain" intervals in the Devonian and elsewhere [8]. The frequencies of N/R alternation (reversion rates) vary over the geomagnetic scale, visually divisible into the magnetochrons of constant polarity ( $\mathrm{N}$ or $\mathrm{R}$ ), those with one or another polarity prevailing ( $\mathrm{Nr}$ or $\mathrm{Rn})$, and mixed $(\mathrm{M})$, with the alternative polarities about equally represented.

Prominent over the geomagnetic sequences are the long intervals of near constant polarity, traditionally recognized as superchrons or hyperchrons with no or a few short-time reversals, such as the Cretaceous Normal Superchron (Aptian-Santonian, 84-125 Ma), Carboniferous-Permian Kiaman Reversed Polarity Hyperchron ( Bashkirian-Wardian, 265-315 Ma), Devonian Sayan Hyperchron (Lokhkovian-Eifelian, 302-415 Ma), and the Ordovician Mayero Reversed Polarity Superchron, (Tremadocian-Arenigian (Dariwillian/Sandbian), 466-484 Ma). They are natural divisions of the geomagnetic polarity scale, although somewhat arbitrary defined, with traditional designations sometimes referring to the history of geomagnetic research rather than the dynamics of reversals.

The reversed - normal ( $\mathrm{Rn})$ sequences of prevailingly reversed polarity, punctuated by the much shorter normal intervals, include the Celasian-Calabrian, mid-Rupelian, Lutetian - mid-Danian (29-64 Ma) of the C-Sequence, the Kimmeridgian - early Tithonian (150-156 Ma) of the M-sequence, as well as the larger parts of the Sinemurian, Norian, Carnian, and Ladinian stages, interrupted by the shorter $\mathrm{Nr}$ intervals at their boundaries. In the Paleozoic, the analogous $\mathrm{Rn}$ series are recorded in the Visean and Tournaisian stages, but the more prominent in the Middle and Late Paleozoic magnetochrons are the $\mathrm{Nr}$ series with relatively long $\mathrm{N}$ intervals, as over the Chaghsingian/Wuchiapingian transition, in the upper Tournaisian, upper Famenian, Eifelian, Wenlockian and lower Tremadocian. Since reversed state is statistically more normal than the "normal" (present day) state, Rn intervals convey relative geomagnetic stability.

The mixed magnetochrons (M) of frequent (about 2.5 myr or less) reversals, with nearly equal duration of normal and reversed components, extend over the long stratigraphic intervals in the M-Sequence and the Carboniferous mixed magnetochron, including the upper Visean, Pridolian-Ludlowian, Llandoverian, Caradocian (Sandbian-Early Katian), and the Early-mid-Cambrian series. 
Mixed intervals are also discernible in the Pliensbachian-Aalenian, 190-175 Ma, Berriasian - Hauterivian, 136-146 Ma, and Ruppelian - Aquitanian, 33-21 Ma. Relatively short (less than 5 myr) mixed intervals occur at the Late Changsingian part of the Late Permian Illavara Series, 251-264 Ma, as well as across the Maastrichtian/Danian, Ruppelian/Chattian, Tortonian/Early Messinian, and Zanclean/Placenzian transboundary intervals. The Marine
Magnetic Anomaly series, Late Bathonian-Kimmeridgian, is assigned a mixed interval of extremely frequent reversals [7], but can also be interpreted as a quiet interval.

In respect to the metrics of reversals, the geomagnetic scale is periodic, with the constant (semiconstant) and mixed intervals conveying periodic alternation of relatively quiet (Q) and agitated (A) geomagnetic field. The first order Q/A cycle chronology is represented in Table 2.

Table 2. Geomagnetic cycles of constant (semiconstant) - mixed polarity magnetochrons (quiet/agitated dipole field states, Q/A) compared to the first order sea level cycles (Table 1).

\begin{tabular}{|c|c|c|c|c|}
\hline I order magnetochrons & Traditional name & Stage & Ma & Epeirochron \\
\hline \multirow{3}{*}{$\begin{array}{l}\text { AI } \\
530-484 \\
\text { Q1 } \\
484-395\end{array}$} & Early - mid-Cambrian (M) Series & Tommotian-Tremadocian & $530-484$ & SLL1, $550-522$ \\
\hline & \multirow[t]{2}{*}{$\begin{array}{l}\text { Mayero }(R) \text { superchron - Sayan }(\mathrm{Rn}) \\
\text { hyperchron and intervening N/M series }\end{array}$} & Tremadocian-Arenigian & $484-475$ & \multirow[t]{2}{*}{ SLH1-1, $522-428$} \\
\hline & & $\begin{array}{l}\text { Caradockian } \\
(\mathrm{Rn}) \\
\text { Ashgillian } \\
(\mathrm{N}) \text {, } \\
\text { Wenlockian }(\mathrm{N}) \text {, Silurian } \\
\text { "mixed polarity } \\
\text { intervals" } \\
\text { Lokhovian- Eifelian (Rn) }\end{array}$ & $\begin{array}{l}491-450 \\
450-443 \\
428-423 \\
443-428 \\
425-416 \\
416-395\end{array}$ & \\
\hline $\begin{array}{l}\text { AII } \\
395-265\end{array}$ & \multirow[t]{2}{*}{$\begin{array}{l}\text { Late Devonian }(\mathrm{N} / \mathrm{T})- \\
\text { Carboniferous }(\mathrm{M}) \text { series }\end{array}$} & Eifelian - Famennian & $395-365$ & \multirow[t]{2}{*}{ SLL2-1, $428-335$} \\
\hline \multirow{5}{*}{$\begin{array}{l}\text { QII } \\
\text { AIII } \\
172-315\end{array}$} & & Famennian - Bashkirian & $365-265$ & \\
\hline & \multirow{3}{*}{$\begin{array}{l}\text { Kiaman }(\mathrm{R}) \text { Hyperperchron } \\
\text { Illawara series }(\mathrm{Rn} / \mathrm{M})- \\
\text { Sn1 -E series }(\mathrm{Rn})\end{array}$} & Bashkirian - Wardian & $325-267$ & \multirow[t]{2}{*}{ SLL2-2, $335-230$} \\
\hline & & Capitanian -Changsingian & $325-267$ & \\
\hline & & $\begin{array}{l}\text { Induan - Anisian } \\
\text { Ladinian - Rhaetian }\end{array}$ & $\begin{array}{l}251-243 \\
237-202\end{array}$ & SLH2, $230-34$ \\
\hline & $\mathrm{M}$ series $(\mathrm{M} / \mathrm{Rn})$ & Bajocian - Barremian & $172-125$ & \\
\hline $\begin{array}{l}\text { QIII } \\
125-30\end{array}$ & $\begin{array}{l}\text { Cretaceous }(\mathrm{N}) \text { superchron - } \\
\text { C33 }(\mathrm{N}) \\
\text { C } 32-\mathrm{C} 12(\mathrm{Rn})\end{array}$ & $\begin{array}{l}\text { Aptian - Campanian } \\
\text { Maastrichtian - Rupelian }\end{array}$ & $\begin{array}{l}125-84 \\
84-71 \\
71-30\end{array}$ & \\
\hline $\begin{array}{l}\text { AIV } \\
30-0\end{array}$ & C11 - C1 (M/Rn) & Rupelian - Present & $30-0$ & SLL3, $0-34$ \\
\hline
\end{tabular}

\subsection{Correlation}

Juxtaposing the sequences of sea level change and geomagnetic reversals (Tables 1,2 ) we find that long intervals of constant polarity designated as hyperchrons or superchrons correspond to the high or normal (near the statistic norm in Fig. 1) sea level stands.

The major sea level lows dividing the first order epeirochrons occur during the normal to mixed Early Cambrian series, the (Visean) Serpuchovian-Bashkirian mixed interval, the Late Changhsingian mixed interval of the Illavara Series, and the predominantly mixed Zanclean - present day interval.

Of the Paleozoic secondary peaks, the Early Ordovician at about the Tremadocian/Arenigian boundary, $478 \mathrm{Ma}$ falls in the Mayero Superchron. The highest Late Ordovican peak, $458 \mathrm{Ma}$, occurs in the relatively long Caradocian reversed interval of a mixed sequence. The Silurian peak, $428 \mathrm{Ma}$ corresponds to the Wenlockian (Homerian) long normal interval. The Devonian high, $387 \mathrm{Ma}$, belongs to the "poorly studied" transitional interval.

The Paleozoic second order sea level lows at or near the Ordovician/ Silurian, $443 \mathrm{Ma}$, Silurian/Devonian, $400 \mathrm{Ma}$, and Devonian/ Carboniferous, $357 \mathrm{Ma}$, boundaries all correspond to the mixed polarity intervals.

In the Meso-Cenozoic megacycle, the Carnian/Norian high, 213 Ma occurs in the long Rn sequence. The Jurassic highs correspond to the Quiet zone. The peak of the broad Cretaceous high corresponds to the end of the Cretaceous Normal Superchron. The Paleogene peak somewhat below the Ipresian/Lutetian boundary, $53 \mathrm{Ma}$, occurs in Rn interval. The Miocene high, $12 \mathrm{Ma}$ falls in the mixed Serravalian/Tortonian interval, but with conspicuously broader reversal intervals than on the flanks of it.

The Meso-Cenozoic lows at the Hettangian/Sinemurian, $197 \mathrm{Ma}$, early Valanginian, $138 \mathrm{Ma}$, and Rupelian/Chattian, $28 \mathrm{Ma}$ all correspond to the mixed polarity intervals.

Thus, correlation of geomagnetic reversal frequencies with sea fluctuation based on arbitrary division of the geomagnetic polarity scale into constant $(\mathrm{N}, \mathrm{R})$, semiconstant $(\mathrm{Rn})$ and mixed (NR) intervals reveals that sea level peaks tend to coincide with constant and semiconstant magnetochrons, whereas sea level troughs are more often confined to mixed polarity magnetochrons. The statistics of elementary geomagnetic events (individual bands of the geomagnetic polarity scale) confirm that long duration events cluster 
at or near the sea level peaks, whereas short duration events consistently prevail over depressions of sea level curve (Fig. 2).

Both sea level changes and the rates of geomagnetic reversal are cyclic; their Paleozoic and Meso-Cenozoic first order cycles coincide or broadly overlap. The boundaries of the mid-Paleozoic Q1 geomagnetic polarity cycle defined by hyperchrons (superchrons), their most prominent metric components, are considerably displaced against the respective sea level cycle SLL1, with the most obvious discrepancies in the vicinity of the Sayan hyperchron, the metrics of which is insufficiently studied, and the ambiguous Devonian intervals.

However, when the geomagnetic polarity scale is plotted as a sequence of individual reversal intervals irrespective of their visual clustering (Fig. 1), the polynomial trend lines for seal level and polarity reversal graphs are conformable (Fig. 1 ), with the peaks and troughs of the first order cycles nearly coinciding.

\section{Discussion}

The correlation of sea level and geomagnetic reversal rate bears on the presently controversial causal interpretations of sea level change, for which the glacioeustasy, hydrospheric geoid effects, and tectonically driven epeirogeny are the basic alternatives. Local sea level fluctuations may result from a cumulative or even synergistic effect of multiple factors, but global changes require an adequate causation.

\subsection{Sea Level Models}

Eustasy directly relates global sea levels to sea water volume fluctuations in respect to the water inputs from melting ice and other sources, as well as by thermal expansion. Originally applied to the Pleistocene sea level changes, the mechanism of glacioeustatic fluctuations has been extrapolated over the geological history, including the non-glacial periods. A correlation of sea level highs with non-glacial climate holds for the Late Cretaceous, but does not hold for the deep and broad low over the Permian-Triassic transition that includes the Late Permian deglaciation, as well as the Early Triassic climate warming. On the other hand, the widespread Hirnantian glaciation [9, $10]$ is associated with the relatively modest sea level low over the Ordovician/Silurian boundary.

Moreover, metrics of the second order sea level cycles is much the same for the glacial and non-glacial periods. The effect of water volume on sea level is not direct, but mediated by isostasy (gravitational equilibration of surface loads depending on their density) and is thereby correlated with the total area and dispersal of the ice (water) covered land masses. This problem is still insufficiently understood, but in view of its widely variable contribution, glacioeustasy is scarcely a universal factor of global sea level change.

Isostasy is commonly involved in geodynamic assessments of ice load and post-glacial rebound, but is actually a more general phenomenon applicable to both hydrosphere and lithosphere and involving eustasy as an additional source of hydrospheric load. Isostasy thus relates sea level to the density heterogeneity of oceanic and continental crust, explaining in the most general terms why these crust domains are equilibrated at different hypsometric levels, regulating the distribution of sea water over the Earth's surface (Fig. 3). The isostatic model thus implies that sea level changes are not (not only) a hydrospheric, but also and foremost the geodynamic phenomenon.

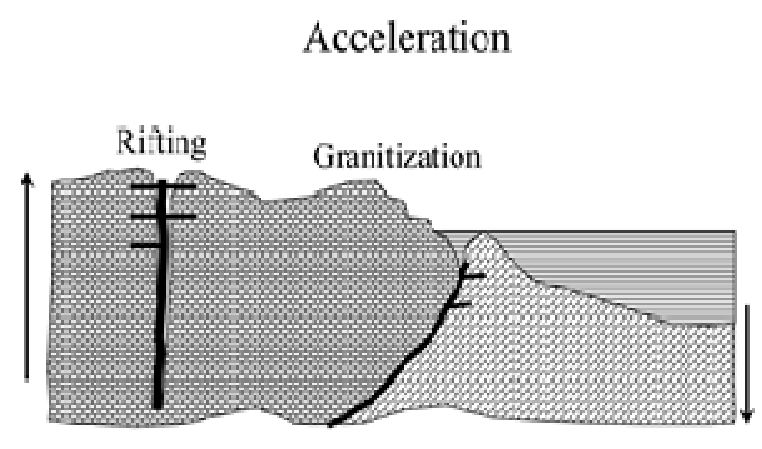

\section{Deceleration}

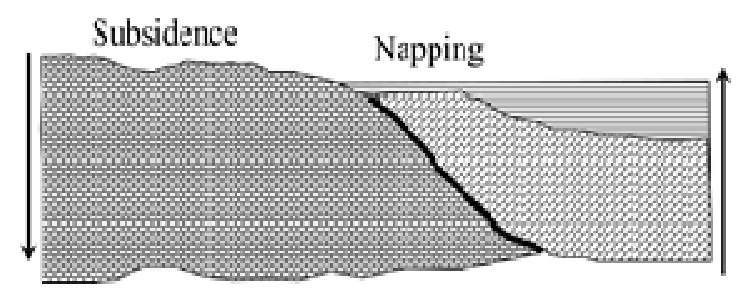

Figure 3. Scheme of sea level change (shore line onlap) as a result of the rise/subsidence (arrows) of continental crust (darker shade) relative to oceanic crust at acceleration and deceleration of Earth's rotation rates.

The epeirogenic sea level fluctuations are currently related to the Earth's mantle convection with both local and global tectonic effects, such as expansion of oceanic ridges, reduced capacity of oceanic depressions, as well as thermal subsidence of oceanic lithosphere with the opposite effect. Direct correlation between sea level and sea floor spreading rates [11] is unlikely on account of the accompanied magmatic and metamorphic processes inflicting density changes, such as impregnation of lithosphere with mantle plumes [12] and metamorphic phase transitions [13], thus inevitably involving isostatic forcing.

The supposed effects of extraterrestrial impacts have been involved in explanation of the Devonian sea level changes [14], although no compelling evidence was presented. In any case, the effect of a giant impact will be isostatic in the first place.

Rotation sea level forcing was advanced as a heuristic approach to the problem of Pleistocene eustatic cycles [15-20] developed in respect to the density-depended acceleration of oceanic and continental crust [2, 21-24]. The major premise of rotation geodynamics is that differential acceleration of density heterogeneous masses generates both 
hydrostatic and divaricate stresses, causing displacement and redistribution of masses on the Earth' surface and in the interior. The oceanic and continental crust domains are isostatically equilibrated at different hypsometric levels that diverge under acceleration and converge under deceleration of the Earth's rotation rates, resulting in the, respectively, steeper or gentler slope of the geoid hypsometric curve and retreat (regression) or advance (transgression) of shore lines (Fig. 3). It is shown [23, 24] that the geoid hypsometric curve had an appreciably gentler slope and was more like that of the Moon when about $60 \%$ of the present day land masses have been covered with epicontinental seas at the peak of Late Cretaceous transgressions.

The role of rotation forcing can be assessed by correlation of global sea level change with the other geodynamic processes driven by Earth's rotation, but of no direct effect on sea level. Insofar as geomagnetic reversals have no appreciable effect on sea level and vice versa, their correlation is mediated through rotation forcing.

\subsection{Geomagnetic Reversal - Sea Level Correlation}

The origin of geomagnetic field is currently related to differential rotation of the solid inner core and the fluid outer core, acting as stator and rotor of a synchronous electric motor, the fluid core flowing eastward over the solid inner core [25-27]. Reversals of dipole geomagnetic field arise in this model under the combined action of centrifugal and Carioles forcing, producing the helical convection flow.

A prediction of the rotation sea level model is that periodicities of sea level change and geomagnetic reversals are chronologically correlated in respect to the alternative acceleration/retardation trends of the Earth's rotation rates, the sea level highs and lows roughly corresponding to the quiet and agitated states of geomagnetic field recorded as alternation of constant and mixed magnetochrons of the geomagnetic scale.

Our results confirm chronological correlation between sea level and geomagnetic events: the dipole geomagnetic field tends to be more stable ("quiet") in terms of reversal frequencies during thalassocratic periods of high sea level, while it is relatively unstable ("agitated") during geocratic periods of low sea level. Because sea level change and geomagnetic events are generated at different depths and involve different mechanisms (i.e. isostasy of heterogeneous crust domains and decoupling of the solid/fluid core layers, respectively), their chronological correlation is only meaningful in respect to differential rotation forcing of both exospheric and endospheric masses.

Considering that geochronological dating of the global sea level and geomagnetic reversals are extrapolations of regional age assignments, and allowing for a time lag between the detectable sea level and geomagnetic effects of a rotation forcing, their more precise correlation than in Fig. 2 does not seem realistic. At the same time, the trend lines of the sea level and geomagnetic reversal curves convey the conformable periodicities of both processes. Their first order cycles roughly correspond to the higher rank divisions of geochronological scale, and the boundaries of the lower order epeiro- and magnetochrons in many cases coincide with the geochronological age/stage boundaries.

The alternation of sea level highs and lows appears more regular in respect to the statistically normal sea level represented as the standard deviation in Fig. 2. The mid-Paleozoic and Meso-Cenozoic sea level rises are nearly symmetrical, 187 myr and 196 myr, respectively, whereas the first order late Paleozoic - Early Mesozoic low between them is of a comparable duration (144 myr), thus revealing the metrics of the first order sea level cycles. The duration of the previous geocratic period suggests that the late Cenozoic (Oligocene -Present) sea level low amounts to about a quarter (34 myr) of the expected first order epeirochron duration and will last for about 100 myr more.

\section{Conclusion}

The generalized sea level and geomagnetic polarity curves are juxtaposed to reveal their chronological correlation predictable on the basis of the rotation geodynamic model, in which the density-dependent acceleration is a common pacesetter of both epeiric and geomagnetic events. Global sea level changes are related to the density-dependent centrifugal acceleration of oceanic and continental crust isostatically equilibrated at different hypsometric levels [2]. Geomagnetic reversals are generated by the density-dependent Carioles forcing across the solid inner core/fluid outer core boundary [25-27].

The global sea level curve reveals periodic alternation of highs and lows representing the first and second order transgression - regression cycles. The geomagnetic polarity scale is likewise periodic and divisible into constant (semiconstant) and mixed polarity magnetochrons, representing the relatively quiet and agitated states of geomagnetic field. The global sea level highs and lows roughly correspond to the quiet and agitated states of geomagnetic field (constant and mixed intervals of geomagnetic polarity scale) respectively.

The chronological correlation of epeirogeny and geomagnetic field evolution is revealed by the conformity of the global sea level and geomagnetic polarity polynomial trend lines (Fig. 2) and the metric congruence of the first and second order cycles. The first order epeirochrons and magnetochrons correspond to the higher rank geochronological divisions (erathems, systems), while the turning points of sea level and geomagnetic polarity trends coincide with stage boundaries thus betraying natural periodicity at the roots of geochronological scale. The metrics of epeiric/geomagnetic cycles gives some grounds for predicting duration of the present geocratic epoch.

\section{References}

[1] R.J. Huggett, "Fluvialism or diluvialism? Changing views on superfloods and landscape change". Progr. Phys. Geogr., vol. 18, pp. 335-342. September 1994. 
[2] V.A. Krassilov, Terrestrial Palaeoecology and Global Change. Sophia: Pensoft, 2003.

[3] J.W. Snedden, C.A. Liu, ”A compilation of Phanerozoic sea-level change, coastal onlaps and recommended sequence designations". Search and Discovery Article 40594. ExxonMobil Production Deutschland GmbH, 2010, www.searchanddiscovery.org.

[4] J. Hardenbol, J. Thierry, M.B. Farley, T. Jacquin, P.C. Graciansky, and P. Vail, "Mesozoic and Cenozoic sequence chronostratigraphic framework of European basins", In Mesozoic and Cenozoic Sequence Stratigraphy of European Basins, P.C. Graciansky et al. Eds. SEPM Special Pub. no. 60, 1998, pp. 3-13.

[5] B.U. Haq and Al-Qahtani, "Phanerozoic cycles of sea-level change on the Arabian Platform". GeoArabia, vol. 10, no. 2, pp.127-160, 2005.

[6] B.U. Haq and S.R. Shutter, "A chronology of Paleozoic sea-level changes". Science, vol. 322, pp. 64-68, October 2008 .

[7] J.G. Ogg, G. Ogg, and F.M. Gradstein, Concise Geologic Time Scale. Cambridge: University Press, 2008.

[8] M. Kono, "Palaeomagnetism and palaeointensity studies of Scottish Devonian volcanic rocks". Geophys J. Intern., vol. 56, no. 2, pp. 385-396, February 1979.

[9] A. Delabroye, and M. Vecoli, "The end-Ordovician glaciation and the Hirnantian Stage: A global review and questions about Late Ordovician event stratigraphy". Earth-Sci. Rev., vol. 98 , no. 3, pp. 269-282, 2010.

[10] S. Finnegan, K. Bergmann, J.M. Eiler, D.S. Jones, D.A. Fike, I. Eisenman et al. "The magnitude and duration of Late Ordovician-Early Silurian glaciation". Science, vol. 331, no. 6019, pp.903-906, February 2011.

[11] C.G.A. Harrison, "Long term eustasy and epeirogeny in continents." In Sea-level Change, Geophysics Study Committee, National Research Council, Ed. Washington D.C.: Academic Press, 1990, pp. 141-158.

[12] D.M. Pechersky, "The geomagnetic field at the Paleozoic/Mesozoic and Mesozoic/Cenozoic boundaries and lower mantle plumes". Izvestiya, Phys. Solid Earth, vol. 43, no. 10, pp. 844-854, 2007.

[13] E.V. Artyushkov and P.A. Chekhovich, "Mechanisms of sea-depth changes in Silurian epeiric basins of east Siberia". Russian Geol. Geophys., vol. 45, no 11, 1219-1236, 2004.

[14] C.A. Sandberg, J.R. Morrow, and W. Ziegler, "Late Devonian sea-level changes, catastrophic events, and mass extinctions".
Geol. Soc. Amer. Spec. Paper, 356, pp. 356-473, 2002.

[15] N.-A. Mörner, "Eustatic changes during the last 300 years. Palaeogeogr. Palaeoclim. Palaeoecol., vol. 13, no. 1, pp. 1-14, March 1973.

[16] N.-A. Mörner, "Eustasy and geoid changes as a function of core/mantle changes". In Earth Rheology, Isostasy and Eustasy, N.-A. Mörner, Ed. N. Y.: Wiley, 1980, pp.535-553.

[17] N.-A. Mörner, "The concept of eustasy: a redefinition". J. Coastal Res. Special issues 1, pp. 49-51, 1986.

[18] N.-A. Mörner, "Models of global sea level changes". In Sea level Changes, M.J. Tooley and I. Shennan, Eds. Oxford: Blackwell, 1987a, pp. 333-355.

[19] N.-A. Mörner, "Eustasy, geoid changes and dynamic sea surface changes due to the interchange of momentum". In Late Quaternary Sea-Level Changes, Y. Quin and S. Zhao, Eds. Beijing: China Ocean Press, 1987b, pp. 26-39.

[20] N.-A. Mörner, "Sea-level changes and Earth's rate of rotation”. J. Coastal Res., vol. 8, no. 4, pp. 966-971, Autumn, 1992.

[21] V.A. Krassilov, Plate tectonics and rotational dynamics of the planet. Izvestia Acad. Sci. U.S.S.R, Geol., no. 1, pp. 74-82, 1976. (В.А. Красилов, “Тектоника плит и ротационный режим планеты”, Известия Акад. Наук СССР, сер. Геол. № 1, C. 74-82, 1976).

[22] V.A. Krassilov, "Organic evolution and natural stratigraphical classification”. Lethaia, vol. 11, no. 2, pp. 93-104, April 1978.

[23] V.A. Krassilov, Cretaceous Period. Evolution of Earth Crust and Biosphere. Moscow; Nauka, 1985. (В.А. Красилов, Меловой период. Эволюция земной коры и биосферы. Москва: Наука, 1985).

[24] V.A. Krassilov, "Overview of rotational geodynamics", Pacific Geology, no. 1. pp. 89-95, April 1991. (B.A. Красилов, “Обзор ротационной геодинамики" Тихоок. Геол., № 1, С. 89-95, 1991).

[25] G.A. Glatzmaier and P.H. Roberts, "A three-dimensional self-consistent computer simulation of a geomagnetic field reversal", Nature, vol. 377, pp. 203-209, 21 September 1995.

[26] G.A. Glatzmaier and P.H. Roberts, "Rotation and magnetism of Earth's inner core', Science, vol. 274, no. 5294, pp. 1887-1891, December 1996.

[27] P.L. Olson, G.A. Glatzmaier, and R. Coe, 2011. "Complex polarity reversals in a geodynamo model”, Earth Planet. Sci. Let., vol. 304, pp.168-179, April 2011. 